\title{
Penanganan scabies pada kucing mix-persia di Rafa Pet's Care
}

\author{
Adik Putri Fatma ${ }^{1, *}$, Ajeng Erika Prihastuti ${ }^{2}$, Reza Yessica ${ }^{3}$, \\ Ida Bagus Gede Rama Wisesa ${ }^{3}$, M. Fadli ${ }^{4}$ \\ ${ }^{1}$ Program Study Pendidikan Profesi Dokter Hewan, Fakultas Kedokteran Hewan, Universitas Brawijaya, Malang \\ ${ }^{2}$ Laboratorium Kesehatan Masyarakat Veteriner, Fakultas Kedokteran Hewan, Universitas Brawijaya, Malang \\ ${ }^{3}$ Laboratorium Parasitologi Veteriner, Fakultas Kedokteran Hewan, Universitas Brawijaya, Malang \\ ${ }^{4}$ Rafa Pet's Care, Bondowoso
}

\begin{abstract}
ABSTRAK: Scabies merupakan penyakit kulit pada ternak maupun hewan kesayangan yang disebabkan oleh tungau Sarcoptes scabiei atau Notoedres cati pada lapisan korneum kulit. Pemilik mengeluhkan kucing jantan mix-persia bernama Simba keluar rumah selama beberapa hari, kemudian pulang dalam kondisi ada luka diwajah, sering terlihat gelisah dan menggaruk bagian wajah, sedangkan makan dan minum kucing normal. Pemeriksaan fisik tampak rambut kusam, alopesia, terdapat lesi dibagian kepala, terdapat hiperkeratosis dibagian kepala dan telinga bagian luar. Pemeriksaan sitologi dilakukan dengan teknik superfisial skin scraping dan terlihat tungau Notoedres cati. Diagnosa kucing tersebut terkena penyakit scabies/scabiosis. Terapi yang diberikan adalah wormectin ${ }^{\circledR}$ (avermectin) dosis $0,05 \mathrm{ml} / \mathrm{kg}$ bobot badan injeksi tunggal. Hari ke 9 pasca-terapi menunjukkan pemulihan berupa keropeng mulai hilang, lesi akibat garukan kucing mulai mengering dan beberapa bagian rambut yang rontok mulai tumbuh kembali.

Kata kunci:

scabies, Notoedres cati, avermectin, skin scraping
\end{abstract}

\section{- PENDAHULUAN}

Kucing sebagai hewan kesayangan membutuhkan perawatan yang tidak mudah, diperlukan adanya perhatian lebih terhadap status kesehatan, asupan nutrisi yang diperlukan, perawatan fisik terhadap kucing serta manajemen kebersihan kandang dan lingkungan sekitar tempat tinggal. Penyakit kulit merupakan hambatan yang paling sering ditemui dalam pemeliharaan kucing, seperti penyakit kulit yang disebabkan oleh parasit tungau scabies (Yudhana et al. 2021).

Scabies merupakan penyakit kulit pada ternak maupun hewan kesayangan yang disebabkan oleh tungau Sarcoptes scabiei atau Notoedres cati pada lapisan korneum kulit. Penyakit ini merupakan penyakit yang sangat menular dan bersifat zoonosis (Calista et al. 2019). Penyakit ini menular melalui kontak langsung dengan hewan yang terinfeksi. Kucing yang terserang penyakit ini dapat mengalami penurunan kondisi tubuh, memicu terjadiya reaksi alergi dan meningkatkan jumlah leukosit pada tubuh, serta berdampak negatif pula bagi pemelihara karena sifatnya yang zoonosis (Susanto et al. 2020). Tulisan ini melaporkan penanganan kasus scabiosis pada kucing mix persia.

\section{- KASUS}

Sinyalemen: Dokter hewan dari Rafa Pet's Care melakukan housecall, datang kerumah pemilik kucing mix persian jantan bernama Simba berumur 5 tahun, dengan keluhan kucing keluar rumah selama beberapa hari, kemudian pulang dalam kondisi ada luka di wajah, sering terlihat gelisah, dan menggaruk bagian wajah, makan dan minum kucing masih dalam keadaan normal. Pemeriksaan fisik: Bobot badan 4 $\mathrm{kg}$, temperature $38,6{ }^{\circ} \mathrm{C}$, heart rate $120 \mathrm{kali} / \mathrm{menit}$, respiration rate $40 \mathrm{kali} / \mathrm{menit}$, turgor 1 detik dan capillary refill time 1 detik. Temuan klinis: rambut kusam, alopesia, terdapat lesi di bagian kepala, hiperkeratosis dibagian kepala dan telinga bagian luar. Pemeriksaan penunjang: sitologi scraping kulit yang mengalami hiperkeratosis dibagian kepala dan sekitar lesi (Gambar 1). Diagnosa: scabiosis. Prognosa: fausta. Terapi: pemberian antiparasit injeksi tunggal avermectin dosis $0,05 \mathrm{ml} / \mathrm{kg}$ bobot badan.

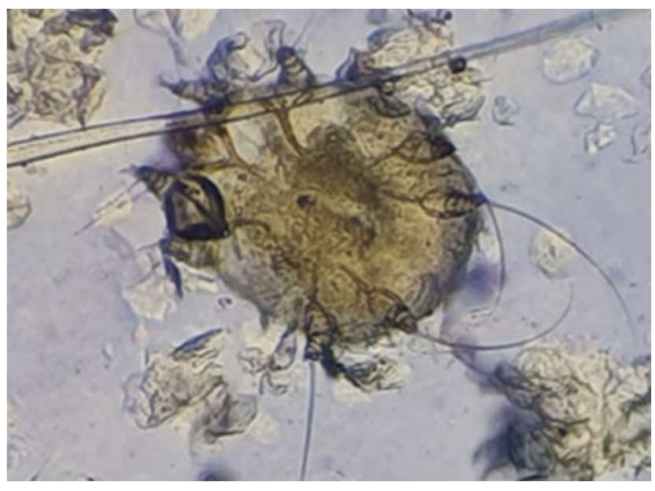

Gambar 1. Tungau Notoedres cati.

Diterima: 20-06-2021 | Direvisi: 03-08-2021 | Disetujui: 10-08-2021

(C) 2021 CC-BY-SA. Ini adalah artikel Open Access yang didistribusikan berdasarkan ketentuan dari Creative Commons Attribution ShareAlike 4.0 International License (https://creativecommons.org/licenses/by-sa/4.0/). 


\section{- HASIL DAN PEMBAHASAN}

Hasil pemeriksaan mikroskop dengan perbesaran 400x didapatkan tungau Notoedres cati (Gambar 1). Secara morfologi Notoedres cati sangat mirip dengan Sarcoptes scabiei (Bagus et al. 2017). Ukuran tungau Notoedres cati lebih kecil dari Sarcoptes scabiei, kulit luar bergaris transversal dan berduri pada Sarcoptes scabiei sedangkan pada Notoedres cati tidak memiliki duri, letak anus Notoedres cati berada dibagian dorsal, sedangkan Sarcoptes scabiei berada di bagian poterior. Sarcoptes scabiei membuat terowongan pada kulit anjing, babi, kambing, kuda dan sapi, sedangkan Notoedres cati pada kulit kucing, kelinci dan tikus

Scabies atau scabiosis adalah penyakit kulit disebabkan oleh tungau dari Family Sarcoptidae antara lain Sarcoptes scabiei dan Notoedres cati (Prasetyo et al. 2019). Kucing simba tertular secara langsung melalui kontak dengan kucing liar yang sudah terinfeksi sebelumnya. Pemilik kucing simba juga mengeluhkan bahwa kucing simba terdapat luka di wajah, sering terlihat ge-lisah, dan menggaruk bagian wajah. Luka di wajah yang di-maksudkan adalah adanya keropeng dan beberapa lesi di bagian wajah dan luar telinga.

Tungau betina yang telah kawin membuat terowongan berkelok-kelok dilapisan atas epidermis, memakan cairan yang berasal dari jaringan yang telah rusak. Selama proses tersebut, tungau betina mengeluarkan sekreta (saliva) dan ekskreta (skibala) sebagai alergen. Alergen masuk kedalam tubuh diproses oleh Antigen Presenting Cell (APC) bersama dengan Major Histocompatibility Complex (MHC) kelas 2, menginduksi limfosit T. Sel Th2 diaktivasi oleh limfosit $\mathrm{T}$ menghasilkan IL-4 dan IL-10 yang menginduksi limfosit B. Hasil dari induksi limfosit B adalah IgE akan mengeluarkan mediator kimia, salah satunya adalah histamin sehingga menyebabkan peningkatan permeabilitas pembuluh darah dan ekstravasasi cairan. Disini terjadi hipersensitifitas tipe 1 berupa pruritus, papula dan vesikula (Baratawidjaja \& Rengganis 2018). Selain itu sekreta dan ekskreta juga dapat menyebabkan lisisnya stratum korneum, sehingga terjadi iritasi dan peradangan pada kulit, hal ini dapat menimbulkan rasa gatal. Rasa gatal membuat kucing menggaruk bagian yang gatal sehingga memicu terjadinya iritasi yang makin parah. Kulit mengeluarkan cairan bening yang membuat kulit menebal, keropeng, serta alopesia.

Terapi yang diberikan dalam kasus ini adalah pemberian wormectin ${ }^{\circledR}$ (avermectin) sebagai antiparasit sebanyak 0,2 $\mathrm{ml}(0,05 \mathrm{ml} / \mathrm{kg} \mathrm{BB})$. Avermectin merupakan turunan ivermectin, antiparasit berspektrum luas terhadap endo- dan ekto-parasit. Selain diberikan antiparasit, dapat diberikan antihistamin untuk mengobati reaksi alergi, mengurangi rasa gatal dan ansiolitik ringan serta obat penenang yang bekerja dengan menghambat histamin pada reseptor $\mathrm{H} 1$ dan dimetabolisme di hati kemudian disekresikan ke dalam urin (Ramsey 2017). Multivitamin (vitamin A, vitamin B6 dan vitamin E) dapat diberikan sebagai suplemen.

Edukasi kepada pemilik kucing Simba sebagai tindakan preventif. Edukasi berupa menjaga kebersihan yang melipu- ti kebersihan kandang, lingkungan, menjaga kebersihan kucing, pemakaian kolar pada kucing selama masa pengobatan sehingga kucing tidak dapat menggaruk bagian yang terinfeksi, menjauhkan kucing yang terinfeksi dengan kucing sehat, penyemprotan desinfektan pada kandang dan lingkungan sekitar, serta rutin memeriksakan kucing ke dokter hewan. Kebersihan pemilik juga perlu diperhatikan mengingat penyakit scabies ini bersifat zoonosis.

Hari ke-9 pasca pemberian terapi dokter hewan Rafa Pet's care melakukan kontrol terhadap kucing simba. Keropeng sudah mulai hilang, lesi yang ditimbulkan akibat garukan kucing sudah mulai mengering, dan beberapa bagian rambut yang rontok mulai muncul kembali. Hal ini menunjukkan bahwa terapi yang dilakukan berhasil dan dapat membunuh Notoedres cati. Pengulangan dosis setelah 14 hari perlu diberikan untuk membunuh Notoedres cati dewasa tahap berikutnya, hal ini karena siklus hidup dari telur menjadi dewasa adalah 10-14 hari (Pudjiatmoko et al. 2014).

\section{- SIMPULAN}

Berdasarkan anamnesa, pemeriksaan fisik dan pemeriksaan penunjang, kucing mengalami scabies oleh tungau Notoedres cati. Terapi wormectin ${ }^{\circledR}$ (avermectin) sebagai antiparasit setelah hari ke-9 menunjukkan adanya pemulihan.

\section{- INFORMASI PENULIS}

Penulis Korespondensi

*APF: adikputrifatma@gmail.com

Program Studi Pendidikan Profesi Dokter Hewan, Fakultas Kedokteran Hewan, Universitas Brawijaya, Kampus UB Dieng, Puncak Dieng Ekslusif, Kalisongo, Kec. Dau, Kab. Malang 65151, Jawa Timur, INDONESIA

\section{- PUSTAKA ACUAN}

Bagus IMO, Made ID, Ida APA, Adisuratma N. 2017. Identifikasi Artropoda. Fakultas Kedokteran Hewan, Universitas Udayana.

Baratawidjaja K, Rengganis I. 2018. Imunologi Dasar, Edisi Kedelapan. Jakarta: Balai Penerbit Fakultas Kedokteran Indonesia.

Prasetyo D, Amri IA, Murwani S, Qosimah D. 2019. Peneguhan diagnosa scabiosis metode sitologi kulit pada kucing domestik di Kota Malang. ARSHI Veterinary Letters. 3(2):27-28.

Susanto H, Kartikaningrum M, Wahjuni RS, Warsito SH, Yuliani MGA. 2020. Kasus scabies (Sarcoptes scabiei) pada kucing di klinik Intimedipet Surabaya. Jurnal Biosains Pascasarjana. 22(1):37-45.

Ramsey I. 2017. BSAVA Formulary: Your questions answered. BSAVA Companion. 2017(6):22-23.

Calista RMDP, Erawan IG, Widyastuti SK. 2019. Laporan kasus: penanganan toksokariosis dan skabiosis pada kucing domestik betina berumur enam bulan. Indonesia Medicus Veterinus. 8(5):660-668.

Yudhana A, Praja RN, Pratiwi A, Islamiyah N. 2021. Diagnosa dan observasi terapi infestasi ektoparasit notoedres cati penyebab penyakit scabiosis pada kucing peliharaan. Media Kedokteran Hewan. 32(2):70-78.

Pudjiatmoko MS, Nurtanto S, Lubis N, Syafrison SY, Kartika D, Yohana CK, Setianingsih E, Efendi ND, Saudah E. 2014. Manual Penyakit Hewan Mamalia. Subdit Pengamatan Penyakit Hewan Direktorat Kesehatan Hewan Direktorat Jenderal Peternakan dan Kesehatan Hewan Kementerian Pertanian. 2nd printing. 2014:438-446. 